\title{
Kurikulum Pendidikan Karakter di Taman Kanak-kanak Negeri Pembina Semarang
}

\author{
Darmu' in \\ Institut Agama Islam Negeri Walisongo Semarang \\ Email: darmuin123@yahoo.com
}

\begin{abstract}
The character education curriculum in Pembina Public Kindergarten Semarang was initiated since 2010 in the form of socializing ideas, internships at kindergarten Budi Mulia 2 Yogyakarta, testing, curriculum development: mapping the character values, aligning the vision, mission, and educational goals. The character values include: religious, honest, tolerance, discipline, hard work, creative, independent, democratic, curiosity, the spirit of nationalism, patriotism, respect for achievement, friendly, peace-loving, fond of reading, environmental care, social care, as well as responsibilities. The assessment of character education is done through observing students and expressed in a qualitative statement. The simulation results of the character education assessment show that the majority of students (67.93\%) have had a character $(M K)$, others $(23.82 \%)$ have begun to develop (MB), a small amount (6.50\%) began to appear (MT), and the rests have not seen yet $(1.14 \%)(C B)$.
\end{abstract}

Keywords: curriculum, instructional, assessment, education, character.

\begin{abstract}
Abstrak
Kurikulum pendidikan karakter di TK NPS dirintis sejak tahun 2010 berupa sosialisasi gagasan, magang di TK Budi Mulia 2 Yogyakarta, melakukan uji coba, penyusunan kurikulum: pemetaan nilai-nilai karakter, menyelaraskan visi, misi, dan tujuan pendidikan. Nilai-nilai karakter meliputi: religius, jujur, toleransi, disiplin, kerja keras, kreatif, mandiri, demokratis, rasa ingin tahu, semangat kebangsaan, cinta tanah air, menghargai prestasi, bersahabat, cinta damai, gemar membaca, peduli lingkungan, peduli sosial, serta tanggung jawab. Penilaian pendidikan karakter dilakukan melalui pengamatan terhadap anak didik, dinyatakan dalam pernyataan kualitatif. Hasil simulasi penilaian pendidikan karakter menunjukkan bahwa anak didik sebagian besar $(67,93$ $\%)$ telah memiliki karakter (MK), sebagian lainnya $(23,82 \%)$ sudah mulai berkembang (MB), sebagian kecil $(6.50 \%)$ mulai terlihat (MT), dan selebihnya $(1.14 \%)$ belum terlihat (BT).
\end{abstract}

Kata kunci: kurikulum, pembelajaran, penilaian, pendidikan, karakter 


\section{A. Pendahuluan}

Muatan nilai-nilai karakter dalam kurikulum TK sesuai dengan Permendiknas nomor 58 tahun 2009 terdapat dalam semua aspek pengembangan, baik dalam aspek pembiasaan maupun dalam aspek kemampuan dasar, namun secara tekstual nilai-nilai karakter tersebut lebih banyak tercantum dalam aspek pembiasaan, yakni bidang pengembangan pembiasaan merupakan kegiatan yang dilakukan secara terus-menerus dalam kehidupan sehari-hari, sehingga anak didik menjadi terbiasa dalam melakukan tingkah laku yang baik. Aspek perkembangan nilai-nilai agama dan moral, bertujuan untuk meningkatkan ketakwaan terhadap Tuhan Yang Maha Esa dan membina sikap anak dalam rangka meletakkan dasar agar anak menjadi warga negara yang baik. ${ }^{1}$

Nilai-nilai agama dan moral meliputi: mengenal Tuhan melalui agama yang dianutnya; meniru gerakan beribadah; mengucapkan doa sebelum dan sesudah melakukan sesuatu; mengenal perilaku baik dan perilaku buruk; membiasakan diri berperilaku baik; mengucapkan salam dan membalas salam. Sedangkan pada TK B Nilai-nilai agama dan moral meliputi: mengenal agama yang dianut; membiasakan diri beribadah; memahami perilaku mulia (jujur, penolong, sopan, hormat, dan sebagainya); membedakan perilaku baik dan buruk; mengenal ritual dan hari besar agama; menghormati agama orang lain. ${ }^{2}$

Aspek perkembangan sosial emosional, dimaksudkan untuk membina anak agar dapat mengendalikan emosinya secara wajar dan dapat berinteraksi dengan sesamanya maupun dengan orang dewasa dengan baik serta dapat menolong dirinya sendiri dalam rangka kecakapan hidup.

Bidang pengembangan sosial emosional bertujuan agar anak didik dapat bergaul dan bekerjasama dengan teman, memiliki sikap toleran, dapat mengekspresikan emosi yang sesuai dengan kondisi yang ada, mengenal tata krama dan sopan santun sesuai dengan nilai sosial budaya setempat, memahami peraturan dan

${ }^{1}$ Hal tersebut sejalan dengan pandangan Miskawaiyh, I.M.A., Tahdhîb al-Akhlâq wa Tathhîr al-A'raq, (Mesir: al-Mathba'ah al-Misriyah, 1934), diterjemahkan dalam bahasa Inggris: The Refinement of Character, oleh Constantine K. Zuraiyk, (Bairut: American University of Beirut, 1968). Dalam bahasa Indonesia: Menuju Kesempurnaan Akhlak, terj. Helmi Hidayat, (Bandung: Mizan, 1994).

${ }^{2}$ Kurikulum tingkat satuan pendidikan (KTSP) TK Negeri Pembina Semarang tahun 2012. 
disiplin, menunjukkan rasa empati, memiliki sikap gigih; bangga terhadap hasil karya sendiri, menghargai keunggulan orang lain.

TK Negeri Pembina Semarang memiliki beberapa program kegiatan yang diintegrasikan dengan kurikulum tersebut, yakni: kurikulum muatan lokal dan pengembangan diri $^{3}$ yang lebih menekankan pada nilai karakter cinta tanah air dan kegiatan pelayanan terhadap diri sendiri. Sedangkan kurikulum yang secara khusus mewadahi nilai-nilai karakter secara khusus tertuang dalam kurikulum pendidikan karakter, kurikulum kewirausahaan, ${ }^{4}$ serta kurikulum kecakapan hidup. ${ }^{5}$ Kurikulum pendidikan karakter di samping terintegrasi dengan kurikulum inti, juga dintergrasikan dengan kurikulum pendidikan kewirausahaan, muatan lokal dan pengembangan diri, pendidikan kecakapan hidup, pendidikan berbasis keunggulan lokal dan keunggulan global yang dikembangkan dalam kurikulum, dibelajarkan serta dinilai secara holistik dan integratif.

\section{B. Pendidikan Karakter bagi Anak Usia Dini}

TK Negeri Pembina Semarang menjadi salah satu TK favorit di Kota Semarang, bahkan di tingkat Propinsi Jawa Tengah. Letaknya di jalan utama jalur Sampangan-Gunungpati di pinggir jalan raya, tepatnya di Jl. Kelud Raya No. 7, bersebelahan dengan SD Petompon di sebelah utara dan deretan ruko di sebelah selatan, sedangkan di seberang jalan terdapat sebuah apotek kecil. Letak TK ini sangat strategis dan mudah dijangkau. Ramainya lalu lintas jalan raya tidak terlalu mengganggu kegiatan pembelajaran karena posisi ruang kelas berada di bagian belakang kompleks TK.

Lokasi TK ini mudah dijangkau dengan kendaraan pribadi atau angkutan umum yang melewati jalan depan TK. Di lingkungan TK ini pula terdapat puskesmas, apotek, fotokopi, dan ruko dengan berbagai bidang usaha. Selain kemudahan akses transportasi, faktor keberadaan usaha pelayanan jasa ini juga memudahkan pendidik dan karyawan jika sewaktu-waktu membutuhkan alat-alat pembelajaran.

\footnotetext{
${ }^{3}$ Kurikulum muatan lokal TK Negeri Pembina Semarang tahun 2012.

${ }^{4}$ Kurikulum pendidikan kewirausahaan TK Negeri Pembina Semarang tahun 2012.

${ }^{5}$ Kurikulum pendidikan kecakapan hidup, pendidikan berbasis keunggulan lokal dan keunggulan global, TK Negeri Pembina Semarang tahun 2012.
} 
Di belakang kompleks TK terdapat perumahan warga yang biasanya digunakan untuk rute jalan-jalan anak didik setiap hari Kamis pagi. Dengan lingkungan yang variatif, dapat membantu pendidik untuk membimbing anak didik dalam pembelajaran di luar kelas. Lingkungan perumahan warga yang kondusif tersebut digunakan pendidik sebagai media pembelajaran bagi anak didik.

Sisi kelemahan lokasi TK ini bangunannya dekat dengan jalan raya sehingga cukup rawan bagi anak didik bila pintu gerbang tidak ditutup. Tanpa bimbingan dari pendidik atau orang tua, anak didik tidak mampu menyeberang jalan. Pendidik mengantisipasinya dengan tidak mengizinkan anak didik keluar gerbang TK sebelum dipastikan ada yang menjemputnya. Di samping itu, suara kendaraan di jalan raya juga membuat suasana di depan gerbang menjadi bising.

Gedung TK yang bersebelahan dengan Sekolah Dasar juga terkadang menimbulkan efek kurang kondusif dalam kegiatan pembelajaran. Beberapa kali kegaduhan di Sekolah Dasar terdengar hingga ke bagian aula TK karena kedua gedung sekolah hanya tersekat satu tembok yang kurang lebih setinggi 2 meter. Sesekali terjadi kasus siswa Sekolah Dasar mengganggu anak didik TK. Padahal banyak siswa Sekolah Dasar tersebut adalah alumni TK Negeri Pembina Semarang. Namun sepanjang pengamatan penulis aktivitas pembelajaran dapat dilaksanakan secara optimal meskipun terdapat sedikit gangguan.

TK Negeri Pembina Semarang dibangun di atas tanah seluas \pm 300 meter persegi dengan posisi datar. Bangunan ini terdapat 11 ruangan terdiri dari 4 ruang kelas, ruang kepala TK, ruang TU, ruang komite, ruang guru, ruang UKS, tempat shalat, dan aula. Di samping itu terdapat beberapa toilet, dua taman bermain anak didik, dan kolam ikan. Di bagian depan terdapat beberapa alat permainan, tempat parkir, dan lapangan upacara.

Kebersihan lingkungan menjadi prioritas perhatian TK Negeri Pembina Semarang, terlihat dengan suasana lingkungan TK yang asri dan tidak ada sedikit pun sampah yang terserak, termasuk di taman bermain. Setiap hari suasana ramai dengan aktivitas anak didik yang bersemangat dalam bermain, belajar, dan bersosialisasi dengan teman sebaya. Posisi bangunan yang saling berhimpitan membuat aktivitas anak didik sering bergerombol.

Keramahan pendidik menjadi sesuatu yang telah membudaya, sebagai bentuk keteladanan terhadap anak didik, terutama pendidik 
senior telah terlatih kesabarannya menghadapi anak didik TK. Setiap anak didik yang datang ke TK, pendidik menyalami anak didik yang sedang berpapasan. Sesekali pendidik berdiri di tengah gerbang untuk menyambut anak didik yang baru datang. Seperti yang pernah dilakukan oleh Sumariyah, pendidik kelas B-3. Sejak pukul 06.45 Sumariyah telah stand by di depan gerbang TK dan menyalami setiap anak didik dan pendidik yang baru datang. Peneliti yang baru datang pun disalami dengan ramah dan dipersilakan masuk. Sesekali ketika ada anak didik yang tampak sedang rewel, langsung digendongnya untuk dihibur dan dirayu dengan permainan menarik bersama teman-temannya, serta disanjung bahwa dia anak yang pintar dan tentunya tidak suka rewel. ${ }^{6}$

Jadwal masuk TK Negeri Pembina Semarang disesuaikan dengan kalender pendidikan pada umumnya, yaitu masuk di Hari Senin hingga Sabtu pukul 07.00 WIB. Masa pendidikan di TK Negeri Pembina Semarang dilaksanakan selama 2 tahun, mulai kelas A (TK nol kecil) hingga kelas B (TK nol besar). Setiap kelas dibagi menjadi empat rombongan belajar. Jadi seluruhnya terdiri dari 8 rombongan belajar: A.1, A.2, A.3, A.4, dan B.1, B.2, B.3, dan B.4. Masing-masing rombongan belajar terdiri dari 20 sampai 22 anak didik yang dipandu oleh dua orang pendidik. Setiap pendidik yang berhalangan mengajar digantikan oleh pendidik dari kelas lain yang masuk di jam berbeda, agar pendidik tidak kesulitan jika memandu pembelajaran sendirian, misalnya pendidik kelas pagi digantikan oleh pendidik kelas siang, atau sebaliknya.

Karena keterbatasan ruang belajar, TK Negeri Pembina Semarang membuka kelas pagi dan siang. Kelas pagi masuk pukul 07.00 dan pulang pukul 09.30 terdiri dari kelas A.1, A.2, A.3, dan A.4, sedangkan kelas siang masuk pukul 09.00 dan pulang pukul 11.30 terdiri dari kelas B.1, B.2, B.3, dan B.4. Hari Senin dan Kamis semua kelas masuk pagi pukul 07.00 dan pulang pukul 09.30. Hari Senin seluruh anak didik masuk pagi untuk mengikuti Upacara Bendera, sementara hari Kamis jalan-jalan berkeliling melewati beberapa gang di sekitar kompleks TK. Pada hari tersebut, siswa kelas A melakukan kegiatan pembelajaran di ruang kelas, sementara kelas B melaksanakan kegiatan pembelajaran di Aula dan kantor pendidik.

${ }^{6}$ Observasi saat anak didik bermain bersama sambil belajar, Selasa, 27 September 2011, pukul 07.00-07.30 WIB., di Aula TK Pembina Semarang. 
Pendidik memandu pembelajaran dengan melakukan pendampingan secara penuh setiap aktivitas anak didik sejak berangkat ke TK hingga dijemput pulang oleh kerabatnya. ${ }^{7}$ Ativitas pendidik TK Negeri Pembina Semarang dalam mendampingi anak didik selama beraktivitas di kelas sangat padat, sehingga perlu menyiapkan perangkat pembelajaran pada hari sebelumnya. Meskipun pembelajaran selesai pada pukul 11.30, pendidik baru bisa pulang sekitar pukul 13.00-14.00 setiap hari.

Setiap pagi, sebelum mulai melaksanakan kegiatan pembelajaran di kelas, anak didik dikumpulkan menjadi satu kelompok di aula untuk belajar sambil bermain bersama. Kegiatan ini diisi dengan berbagai macam permainan, seperti memperagakan yelyel, bernyanyi, bercerita, dan ceramah-ceramah ringan dari guru. Contoh yel-yel yang sering digunakan adalah "Tepuk Disiplin". Sedangkan contoh nyanyian sederhana yang cukup menarik dan mengandung nilai-nilai karakter adalah lagu Ibu Guruku.

Sekitar setengah jam kegiatan di aula, dilanjutkan kegiatan pembelajaran di ruang kelas. Pertama, pendidik membuka pelajaran dengan mengajak anak didik berdoa dan menyapa anak didik dengan salam dan menanyakan kabar. Kemudian pendidik memberikan sedikit materi dengan ceramah dan tanya jawab. Terkadang pendidik memulai pembelajaran dengan membuat permainan sederhana. Kemudian anak didik diberi pengarahan untuk melaksanakan tugas-tugas tertentu di area-area yang tersedia. Biasanya anak didik dibagi menjadi tiga atau empat kelompok untuk melaksanakan tugas di area yang berbeda secara bergantian.

Kegiatan yang durasi waktunya paling lama pelaksanaannya adalah belajar sambil bermain yang dilaksanakan di area belajar tersebut. Pada kegiatan ini pendidik melakukan pengawasan sambil melakukan pembimbingan langsung. Penilaian harian juga dilakukan pada saat kegiatan ini, pendidik merangsang keaktifan anak didik, kemudian mengukur sejauh mana perkembangan yang telah dicapai anak didik pada saat itu.

${ }^{7}$ Wawancara dengan Suliyem Kepala TK Negeri Pembina Semarang, Kamis, 15 September 2011, pukul 11.00-11.30 WIB, di Kantor Kepala TK Negeri Pembina Semarang.

8 Observasi kegiatan belajar sambil bermain, Jumat, 23 September 2011, pukul 07.00-07.30 WIB., di Aula TK Negeri Pembina Semarang. 
Menjelang pukul 09.00 pembelajaran diisi dengan kegiatan makan bersama. Anak didik biasanya sudah membawa bekal sendiri, berupa makanan dan minuman. Setelah makan, barulah anak didik pulang dengan dijemput kerabat masing-masing. Begitu juga yang dilakukan dengan kelompok belajar kelas siang. Selain itu juga ada kegiatan yang hanya dilaksanakan pada hari tertentu, yaitu pembelajaran agama Islam setiap Hari Senin dan Kamis, pembelajaran agama Katolik setiap Hari Rabu, Upacara Bendera setiap Hari Senin, Jalan-jalan setiap Hari Kamis, berlatih menari setiap Hari Rabu, dan berlatih musik tradisional Kulintang setiap hari Sabtu.

\section{B. Implementasi Pendidikan Karakter di TK Negeri Pem- bina Semarang}

1. Pengembangan Kurikulum Pendidikan Karakter

Ruang lingkup kurikulum TK Negeri Pembina Semarang didasarkan kepada Peraturan Menteri Pendidikan Nasional Nomor 58 Tahun 2009 tentang standar nasional pendidikan anak usia dini ${ }^{9}$ meliputi: aspek pengembangan pembiasaan dan aspek perkembangan kemampuan dasar. Kurikulum tersebut kemudian dikembangkan sesuai dengan kebutuhan nyata TK Negeri Pembina Semarang dengan memasukkan mulok, dan pengembangan diri, di samping itu juga diintegrasikan dengan pendidikan karakter dan kewirausahaan. ${ }^{10}$

a. Aspek Pembiasaan dan Keteladanan

Aspek pembiasaan meliputi materi pembelajaran tentang nilai-nilai agama dan nilai-nilai sosial emosional. Materi pembelajaran ini merupakan aspek terpenting dalam pendidikan karakter, karena nilai-nilai yang dikembangkan dalam pendidikan karakter termuat dalam nilai-nilai agama dan nilai-nilai moral yakni: religius, jujur, toleransi, disiplin, kerja keras, kreativitas, mandiri, rasa ingin tahu, semangat kebangsaan, cinta tanah air,

${ }^{9}$ Peraturan Menteri Pendidikan Nasional Nomor 58 Tahun 2009 tentang standar nasional pendidikan anak usia dini yang dijadikan pijakan pengembangan kurikulum di TK Negeri Pembina Semarang.

10 Pendidikan karakter di sekolah dapat dibaca dalam: Lickona, T., Educating for Character, How Our Schools Can Teach Respect and Responsibility, (New York: Bantam Books, 1992). 
menghargai prestasi, bersahabat, cinta damai, gemar membaca, peduli lingkungan, peduli sosial, serta tanggung jawab. $^{11}$

Pendidikan agama selain dibelajarkan melalui pembiasaan juga dibelajarkan secara terstruktur dalam pembelajaran yang terprogram ${ }^{12}$ pada hari Senin dan Kamis, sedangkan pendidikan agama Nasrani dibelajarkan pada hari Rabu. ${ }^{13}$ TK Negeri Pembina Semarang memiliki pendidik agama secara khusus, karena pendidik yang bertanggung jawab terhadap masing-masing rombongan belajar dipandang kurang memiliki kualifikasi akademik dan profesional dalam bidang pendidikan agama.

Aspek pembiasaan dan keteladanan dijadikan metode unggulan dalam pendidikan karakter, bahkan dari 16 pendidik yang dijadikan informan dalam penelitian ini semuanya mengemukakan pentingnya pembiasaan dan keteladanan ${ }^{14}$ untuk menanamkan karakter pada diri anak didik. Di samping itu terdapat pula penanaman karakter dalam bentuk pembelajaran, pembudayaan dalam lembaga pendidikan, serta penguatan. ${ }^{15}$

b. Aspek Perkembangan Dasar

Kurikulum aspek perkembangan dasar: 1) Fisik meliputi: motorik kasar; motorik halus; dan kesehatan fisik; 2) Kognitif meliputi: pengetahuan umum dan sains; konsep bentuk warna, ukuran dan pola; konsep bilangan, lambang bilangan, dan huruf; 3) Bahasa meliputi: menerima bahasa; mengungkapkan bahasa; keaksaraan. Standar perkembangan anak TK dikelompokkan menjadi dua: pertama kelompok usia 4 sampai 5 tahun disebut kelompok A; kedua anak usia 5 sampai 6 tahun, disebut kelompok B. 2012.

${ }^{11}$ Kurikulum pendidikan karakter TK Negeri Pembina Semarang tahun

12 Wawancara dengan Sri Hartati, pendidik rombel A 3, Sabtu, 25 Pebruari 2012, pukul 11. 45.00 WIB., di Ruang Guru.

${ }^{13}$ Kurikulum pendidikan agama Islam yang disusun oleh Kurmain, guru PAI TK Negeri Pembina Semarang, tahun 2012.

14 Wawancara dengan Haryati, pendidikan rombel A 4, Senin, 02 Januari 2012, pukul 13.00 WIB., di Ruang Guru.

15 Desain induk pendidikan karakter, Kementerian Pendidikan Nasional tahun 2010 . 
Muatan nilai-nilai karakter dalam kurikulum TK sesuai dengan Permendiknas nomor 58 tahun 2009 terdapat dalam semua aspek pengembangan, baik dalam aspek pembiasaan maupun dalam aspek kemampuan dasar, namun secara tekstual nilai-nilai karakter tersebut lebih banyak tercantum dalam aspek pembiasaan, yakni bidang pengembangan pembiasaan merupakan kegiatan yang dilakukan secara terus-menerus dalam kehidupan seharihari, sehingga anak didik menjadi terbiasa dalam melakukan tingkah laku yang baik.

Aspek perkembangan nilai-nilai agama dan moral, bertujuan untuk meningkatkan ketakwaan terhadap Tuhan Yang Maha Esa dan membina sikap anak dalam rangka meletakkan dasar agar anak menjadi warga negara yang baik. $^{16}$

Nilai-nilai agama dan moral meliputi: mengenal Tuhan melalui agama yang dianutnya; meniru gerakan beribadah; mengucapkan doa sebelum dan sesudah melakukan sesuatu; mengenal perilaku baik dan perilaku buruk; membiasakan diri berperilaku baik; mengucapkan salam dan membalas salam. Sedangkan pada TK B Nilainilai agama dan moral meliputi: mengenal agama yang dianut; membiasakan diri beribadah; memahami perilaku mulia (jujur, penolong, sopan, hormat, dan sebagainya); membedakan perilaku baik dan buruk; mengenal ritual dan hari besar agama; menghormati agama orang lain. ${ }^{17}$

Aspek perkembangan sosial emosional, dimaksudkan untuk membina anak agar dapat mengendalikan emosinya secara wajar dan dapat berinteraksi dengan sesamanya maupun dengan orang dewasa dengan baik serta dapat menolong dirinya sendiri dalam rangka kecakapan hidup.

Bidang pengembangan sosial emosional bertujuan agar anak didik dapat bergaul dan bekerjasama dengan

${ }^{16}$ Hal tersebut sejalan dengan pandangan Miskawaiyh, I.M.A., Tahdhîb al-Akhlâq wa Tathhîr al-A'raq, (Mesir: al-Mathba'ah al-Misriyah, 1934), diterjemahkan dalam bahasa Inggris: The Refinement of Character, oleh Constantine K. Zuraiyk, (Bairut: American University of Beirut, 1968). Dalam bahasa Indonesia: Menuju Kesempurnaan Akhlak, terj. Helmi Hidayat, (Bandung: Mizan, 1994).

17 Kurikulum tingkat satuan pendidikan (KTSP) TK Negeri Pembina Semarang tahun 2012. 
teman, memiliki sikap toleran, dapat mengekspresikan emosi yang sesuai dengan kondisi yang ada, mengenal tata krama dan sopan santun sesuai dengan nilai sosial budaya setempat, memahami peraturan dan disiplin, menunjukkan rasa empati, memiliki sikap gigih; bangga terhadap hasil karya sendiri, menghargai keunggulan orang lain.

TK Negeri Pembina Semarang memiliki beberapa program kegiatan yang diintegrasikan dengan kurikulum tersebut, yakni: kurikulum muatan lokal dan pengembangan diri ${ }^{18}$ yang lebih menekankan pada nilai karakter cinta tanah air dan kegiatan pelayanan terhadap diri sendiri. Sedangkan kurikulum yang secara khusus mewadahi nilai-nilai karakter secara khusus tertuang dalam kurikulum pendidikan karakter, kurikulum kewirausahaan, ${ }^{19}$ serta kurikulum kecakapan hidup. ${ }^{20}$

Selain kurikulum inti yang diintegrasikan dengan beberapa program sebagaiamana telah disebutkan, TK Negeri Pembina Semarang mengembangkan kurikulum pendidikan karakter dengan 18 cakupan nilai-nilai meliputi: religius, jujur, toleransi, disiplin, kerja keras, kreatif, mandiri, demokratis, rasa ingin tahu, semangat kebangsaan, cinta tanah air, menghargai prestasi, bersahabat dan berkomunikasi, cinta damai, gemar membaca, peduli lingkungan, peduli sosial, serta tanggung jawab. Adapun materi pendidikan karakter atau yang dikembangkan sebagaimana tertuang dalam kurikulum pendidikan karakter dapat dipaparkan sebagai berikut.

Kurikulum pendidikan karakter disamping terintegrasi dengan kurikulum inti, juga dintergrasikan dengan kurikulum pendidikan kewirausahaan, muatan lokal dan pengembangan diri, pendidikan kecakapan hidup, pendidikan berbasis keunggulan lokal dan keunggulan

${ }^{18}$ Kurikulum muatan lokal TK Negeri Pembina Semarang tahun 2012.

${ }^{19}$ Kurikulum pendidikan kewirausahaan TK Negeri Pembina Semarang tahun 2012.

${ }^{20}$ Kurikulum pendidikan kecakapan hidup, pendidikan berbasis keunggulan lokal dan keunggulan global, TK Negeri Pembina Semarang tahun 2012. 
global yang dikembangkan dalam kurikulum, dibelajarkan serta dinilai secara holistik dan integratif. ${ }^{21}$

Kurikulum pendidikan kewirausahaan di TK Negeri Pembina Semarang bertujuan mengembangkan nilai-nilai berikut: kerja keras, kepemimpinan, ulet, berani menanggung resiko, komitmen, realistis, serta nilai komunikatif. Adapun kurikulum muatan lokal bertujuan untuk memberi bekal anak didik mampu menggunakan bahasa jawa sebagai bahasa daerah serta memahami makanan khas daerah Semarang. ${ }^{22}$ Sedangkan tujuan kurikulum muatan lokal dan pengembangan diri yang diintegrasikan dengan pendidikan karakter terutama untuk memperkokoh nilai-nilai yang berhubungan dengan karakter cinta tanah air.

Pendidikan karakter dibelajarkan bersama-sama dengan pendidikan kecakapan hidup dengan tujuan agar nilai-nilai karakter yang dimiliki anak didik kokoh dan dapat diaplikasikan dalam kehidupan sehari-hari sehingga dapat membudaya dalam kehidupannya. Adapun pendidikan kecakapan hidup yang dibelajarkan di TK Negeri Pembina Semarang meliputi: melepas memakai (sepatu dan baju), BAK dan BAB, menggosok gigi dan menyisir rambut, makan bersama, melatih kemampuan berinteraksi dengan teman sebaya dan orang dewasa.

Pendidikan karakter juga diperdalam dengan pendidikan berbasis keunggulan lokal dan global, yaitu dengan cara memberikan pengalaman langsung kepada anak didik dalam meningkatkan daya saing sesuai keunggulan potensi daerah yang dimiliki. Di samping itu juga diberikan pendidikan berbasis keunggulan global berupa pendidikan bahasa Inggris, untuk memberi bekal agar anak didik dapat bersaing dalam lingkup internasional.

Pendidikan berbasis keunggulan lokal meliputi: 1) lelang hasil karya anak di setiap akhir tahun pelajaran; 2) menciptakan karya sederhana dari bahan bekas (misal: membuat bunga dari kertas) yang dapat dijual, dengan tujuan: memupuk dan mengembangkan kreativitas anak di

${ }^{21}$ Wawancara dengan Sri Yanti, pendidik rombel B4, Sabtu, 02 Januari 2012, pukul 13.10 WIB., di Ruang Guru.

${ }^{22}$ Kurikulum muatan lokal, TK Negeri Pembina Semarang tahun 2012. 
bidang seni, melatih agar anak menjadi pribadi yang ulet dalam mencapai tujuan dengan berbagai alternatif, memberikan dasar agar anak di masa depannya dapat menciptakan lapangan kerja sendiri, memupuk rasa bangga dengan prestasi sendiri, serta menghargai karya orang lain. Sedangkan pendidikan berbasis keunggulan global adalah memberikan pendidikan bahasa Inggris dengan tujuan mengenalkan bahasa Inggris sebagai bahasa internasional yang perlu diketahui.

Seluruh aspek pengembangan dan standar pengembangan baik yang dimuat dalam kurikulum pokok, kurikulum pendidikan karakter, maupun pendidikan kewirausahaan, kurikulum muatan lokal, serta pendidikan berbasis lokal dan global direncanakan dan dibelajarkan secara terintegrasi dah holistik, tidak dipisahkan antara aspek pengembangan satu dengan yang lainnya, atau antara sub kurikulum yang satu dengan yang lainnya. Dengan demikian dalam kegiatan pembelajaran maupun dalam penilaian pun menjadi satu kesatuan secara terpadu dan tidak terpisah.

\section{Pembelajaran Pendidikan Karakter}

Pembelajaran pendidikan karakter yang dilakukan di TK Negeri Pembina Semarang melalui: keteladanan, pembelajaran, serta dalam pengembangan budaya satuan pendidikan.

a. Keteladanan dan Pembiasaan. Pemberian teladan dan melakukan pembiasaan oleh warga TK Negeri Pembina Kota Semarang terhadap anak didik digunakan sebagai pendekatan utama pelaksanaan kegiatan pendidikan karakter, ${ }^{23}$ misalnya "setelah bermain dirapikan, barangbarang dikembalikan. Setelah makan dibersihkan, untuk menanamkan nilai tanggungjawab". Warga satuan pendidikan berusaha menunjukkan keteladanan yang mencerminkan nilai-nilai karakter yang ingin dikembangkan. Misalnya toilet yang selalu bersih, bak sampah ada di berbagai tempat dan selalu dibersihkan, lingkungan lembaga pendidikan terlihat rapi, dan alat

${ }^{23}$ Wawancara dengan Budi Adingsih, pendidik rombel B 2, Sabtu, 10 Maret 2012, pukul 12.30 WIB., di Ruang Guru. 
belajar ditempatkan teratur. ${ }^{24}$ Selain itu, keteladanan juga ditunjukkan dalam perilaku dan sikap pendidik dan tenaga kependidikan lainnya dalam memberikan contoh tindakantindakan yang baik sehingga menjadi panutan bagi anak didik untuk mencontohnya. ${ }^{25}$ Keteladanan dalam pendidikan karakter dilakukan melalui pengintegrasian ke dalam kegiatan sehari-hari yang berwujud kegiatan rutin, kegiatan yang terprogram, serta kegiatan seketika. ${ }^{26}$

b. Terintegrasi dengan Pembelajaran. Pembelajaran karakter di TK Negeri Pembina Semarang dilakukan melalui berbagai kegiatan di kelas, di satuan pendidikan, serta di luar satuan pendidikan sesuai dengan ketentuan yang diberikan oleh Kemendiknas ${ }^{27}$ meliputi: pembelajaran pendidikan karakter di kelas $^{28}$ dan Pembelajaran pendidikan karakter dalam satuan pendidikan.

c. Pendidikan karakter di luar satuan pendidikan. Pembelajaran karakter dilaksanakan melalui kegiatan insidental dan kegiatan lain yang diikuti oleh seluruh atau sebagian

${ }^{24}$ Selama peneliti mengadakan pengamatan di TK NPS dapat diketahui bahwa situasi umum sarana dan prasana TK NPS sangat bersih dan tertata rapi meliputi: halaman, tempat bermain, kamar mandi, ruang belajar, ruang kepala, TU dan pendidik.

${ }^{25}$ Pukul 6.45 WIB para pendidik sudah berada di halaman TK NPS, mereka menyambut kedatangan anak didik yang diantar dengan cara menyapa, menyalami, dan mempersilahkan masuk di area pembelajaran. Sebelum pembelajaran dimulai biasanya anak didik bermain di taman bermain ditemani oleh para pendidik yang berperan membimbing dan mengarahkan kegiatan permainan mereka sampai pukul 7.00 WIB.

${ }^{26}$ Kegiatan rutin adalah kegiatan yang dilaksanakan secara terus-menerus setiap hari, misalnya: mengucapkan salam ketika datang, meletakkan tas di loker, meletakkan sepatu pada tempatnya, memulai dan mengakhiri kegiatan dengan berdoa, melakukan upacara setiap hari Senin, dan sebagainya. Adapun kegiatan terprogram adalah kegiatan pembelajaran yang dituangkan dalam rencana kegiatan harian. Sedangkan kegiatan seketika adalah kegiatan yang terjadi secara tiba-tiba, bukan kegiatan rutin dan terprogram, misalnya: ada anak yang terjatuh ketika berjalan atau bermain, berselisih dengan temannya, anak ngamabek, anak sakit, anak mau BAK dan BAB, dan sebagainya.

${ }^{27}$ Desain induk pendidikan karakter, Kementerian Pendidikan Nasional, tahun 2010, hlm. 16-17.

28 Pembelajaran di kelas dilaksanakan secara tematik sesuai dengan pandangan Trianto, 2011, Desain Pengembangan Pembelajaran Tematik bagi Anak Usia Dini TK/RA \&Anak Kelas SD/MI Awal, (Jakarta: Prenada Media Group). 
anak didik, dirancang satuan pendidikan sejak awal tahun pelajaran atau program pembelajaran, dan dimasukkan ke dalam kalender akademik.

d. Pengembangan Budaya Satuan Pendidikan. Budaya satuan pendidikan TK Negeri Pembina Semarang memiliki cakupan yang sangat luas, antara lain mencakup kegiatan ritual, harapan, hubungan sosial-kultural, aspek demografi, kegiatan kurikuler, kegiatan ekstra kurikuler, proses pengambilan keputusan, kebijakan, maupun interaksi sosial antarkomponen. Budaya satuan pendidikan TK adalah suasana kehidupan satuan pendidikan di mana anak didik berinteraksi dengan sesamanya, pendidik dengan pendidik, pendidik dengan anak didik, pendidik dengan tenaga kependidikan, antara tenaga kependidikan dengan pendidik dan anak didik, dan antaranggota kelompok masyarakat dengan warga satuan pendidikan TK.

e. Pengintegrasian Pendidikan Karakter dalam Semua Aspek Pengembangan. Pengintegrasian pendidikan karakter ke dalam semua materi pembelajaran dilakukan dalam rangka mengembangkan kegiatan intervensi. Substansi nilai sesungguhnya secara eksplisit atau implisit sudah ada dalam rumusan standar perkembangan anak. Kegiatan pembelajaran dilakukan diupayakan memiliki dampak instruksional dan atau dampak pengiring pembentukan karakter. $^{29}$

f. Integrasi Pendidikan Karakter dalam Kegiatan Rutin. Kegiatan rutin akan semakin bermakna jika diisi dengan berbagai kegiatan bermuatan nilai yang menarik dan bermanfaat bagi anak didik. Kegiatan rutin di TK Negeri Pembina Semarang merupakan kegiatan yang terintegrasi dengan kegiatan kurikuler, sehingga tidak dipisahkan antara satu dengan lainnya. Kegiatan rutin meliputi: upacara setiap hari Senin, ${ }^{30}$ berdoa sebelum memulai dan

${ }^{29}$ Model pendidikan karakter terintegrasi ini dapat dilihat dalam: Zuchdi, D., at. all., Pendidikan Karakter dengan Pendekatan Komprehensif Terintegrasi dalam Perkuliahan dan Pengembangan Kultur Universitas, Cetakan 1, Desember, Yogyakarta: UNY Press, 2010).

${ }^{30}$ Observasi pembelajaran nilai karakter nasionalisme melalui upacara bendera, Senin, 19 September 2011, pukul 07.00-07.30 WIB, di halaman depan TK Negeri Pembina Semarang. 
mengakhiri pembelajaran, berdoa sebelum dan sesudah makan, bersalaman dan mengucapkan salam sewaktu datang dan pulang sekolah, bermain sebelum belajar dan setelah makan, memberi infak setiap hari Jum'at bagi anak didik yang beragama Islam, dan memberikan persembahan pada hari Rabu bagi anak didik yang beragama Nasrani, serta jalan pagi setiap hari Kamis. Setiap kegiatan didampingi oleh pendidik yang membimbing kegiatan tersebut.

g. Pemberdayaan dan Pembudayaan Pendidikan Karakter. Dalam kehidupan sehari-hari di lingkungan satuan pendidikan TK Negeri Pembina Semarang diterapkan dalam bentuk totalitas pendidikan dengan mengandalkan keteladanan, penciptaan lingkungan dan pembiasaan melalui berbagai tugas dan kegiatan. Oleh sebab itu, seluruh hal yang dilihat, didengar, dirasakan, dan dikerjakan oleh anak didik adalah pendidikan. Selain menjadikan keteladanan sebagai metode pendidikan utama, penciptaan lingkungan dan pergaulan dipandang sebagai hal yang sangat penting, karena lingkungan itulah yang ikut membentuk karakter anak didik. Penciptaan lingkungan di TK NPS dilakukan melalui: 1) penugasan, 2) pembiasaan, 3) pelatihan, 4) pembelajaran, 5) pengarahan, serta 6) keteladanan. Semuanya itu digunakan dalam pembentukan karakter anak didik. Penciptaan lingkungan tersebut disesuaikan dengan tingkat perkembangan anak didik, sehingga anak didik akan mengerjakan berbagai macam kegiatan dengan semangat dan merasa senang. Kehidupan sehari-hari di rumah dan di masyarakat juga mendapat perhatian dalam rangka pendidikan karakter. Banyak manfaat yang diperoleh oleh satuan pendidikan dari masyarakat dan sebaliknya. Antara satuan pendidikan dan masyarakat melakukan banyak interaksi. Beberapa komponen masyarakat terutama orangtua dan Komite Sekolah terlibat dalam proses belajar di TK Negeri Pembina Semarang.

h. Penguatan Pendidikan Karakter. Penguatan sebagai respon dari pendidikan karakter di TK Negeri Pembina Semarang dilakukan dalam jangka panjang dan berulang terusmenerus. Penguatan dimulai dari lingkungan terdekat dan meluas pada lingkungan yang lebih luas. Di samping 
pembelajaran dan pemodelan, penguatan merupakan bagian dari proses intervensi. Penguatan juga dapat terjadi dalam proses habituasi. Hal itu akhirnya akan membentuk karakter yang akan terintegrasi melalui proses internalisasi dan personalisasi pada diri masing-masing individu. Penguatan juga dilakukan dalam berbagai bentuk termasuk penataan lingkungan belajar dalam satuan pendidikan yang menyentuh dan membangitkan karakter. Berbagai penghargaan perlu diberikan kepada satuan pendidikan, pendidik, tenaga kependidikan, atau anak didik untuk semakin menguatkan dorongan, ajakan, dan motivasi pengembangan karakter.

3. Penilaian Pendidikan Karakter

Penilaian yang dilakukan di TK Negeri Pembina Semarang dilakukan secara terintegrasi dengan penilaian keseluruhan pada aspek pembiasaan dan kemampuan dasar secara umum dalam kurikulum KTSP sebagaimana dijelaskan oleh Arum, ${ }^{31}$ bahwa penilaian di TK NPS dilakukan dalam bentuk "unjuk kerja, observasi, hasil karya, dan catatan anekdot", menggunakan instrumen penilaian lembar observasi, kemudian dilaporkan "terintegrasi penilaian di TK pada nilai-nilai moral agama, sosial emosional, dan kepada kemampuan dasar: bahasa, kognitif, fisik motorik dan seni'. Masing-masing pendidik memiliki lembar penilaian catatan harian yang digunakan untuk mencatat perkembangan anak didik yang diamati setiap hari sebagaimana ditunjukkan oleh Nining, ${ }^{32}$ kemudian dari catatan harian dan rekap daftar kehadiran dijadikan sebagai dasar untuk membuat laporan semesteran meliputi: aspek pembiasaan (moral dan nilai-nilai agama, sosial, emosional, dan kemandirian; aspek kemampuan dasar meliputi: berbahasa, kognitif, fisik dan motorik, serta seni. ${ }^{33}$

Penilaian pendidikan karakter yang dilakukan tidak terpisah dengan penilaian aspek lainnya, karena masing

${ }^{31}$ Wawancara dengan Purwanti, pendidik rombel A 2, Selasa, 07 Pebruari 2012, pukul 13.10 WIB., di Ruang Guru.

${ }^{32}$ Catatan Harian Nining Setyawati, Pendidik rombel A 1 TK Negeri Pembina Semarang tahun 2012.

${ }^{33}$ Contoh format buku penilaian perkembangan anak didik, TK Negeri Pembina Semarang, tahun 2012. 
pendidik yang telah melakukan penilaian dalam bentuk catatan harian telah memperhatian nilai-nilai karakter yang dikembangkan dan dibelajarkan secara terintegrasi dengan materi pembelajaran lainnya. Misalnya nilai karakter religius dapat diamati ketika membaca doa waktu memulai dan mengakhiri kegiatan, nilai karakter disiplin dapat diamati waktu datang dan pulang tepat waktu, nilai karater toleransi dapat diamati dalam kesediaan bergantian alat bermain, nilai karakter jujur dapat diamati ketika anak didik mau menyampaikan pendapat apa adanya, nilai peduli lingkungan, dapat diamati ketika anak didik membuang sampah, nilai karakter peduli sosial dapat diamati ketika anak didik mau memberikan sebagian bekalnya kepada temannya yang tidak membawa, dan sebagainya sebagaimana tertuang dalam kurikulum pendidikan karakter. Penilaian pendidikan karater diintegrasikan dengan penilaian seluruh aspek pembiasaan dan kemampuan dasar anak didik. Adapun teknik penilaian yang diguankan adalah: pengamatan, unjuk kerja, portofolio/kumpulan tugas, percakapan atau wawancara.

Penilaian pencapaian pendidikan karakter didasarkan pada indikator yang telah ditetapkan. Sebagai contoh, indikator untuk nilai jujur di suatu semester dirumuskan dengan "mengatakan dengan sesungguhnya perasaan dirinya mengenai apa yang dilihat, diamati, dipelajari, atau dirasakan", maka pendidik mengamati (melalui berbagai cara) apakah yang dikatakan peserta didik itu jujur mewakili perasaan dirinya. Mungkin saja anak didik menyatakan perasaannya itu secara lisan tetapi dapat juga dilakukan secara tertulis, bahkan dengan bahasa tubuh. Perasaan yang dinyatakan itu mungkin saja memiliki gradasi dari perasaan yang tidak berbeda dengan perasaan umum teman sekelasnya sampai bahkan kepada yang bertentangan dengan perasaan umum teman sekelasnya.

Penilaian dilakukan secara terus-menerus, setiap saat pendidik berada di kelas atau di luar kelas. ${ }^{34}$ Model penilaian pendidikan karakter melalui anecdotal record

${ }^{34}$ Lihat: Seefeldt, C., \& Wasik, B.A., Pendidikan Anak Usia Dini: Menyiapkan Anak Usia Tiga, Empat, dan Lima Tahun Masuk Sekolah, terj. Pius Nasar, (Jakarta: PT Indeks, 2008), hlm. 235-247. 
(catatan yang dibuat pendidik ketika melihat adanya perilaku yang berkenaan dengan nilai yang dikembangkan) sering digunakan oleh pendidik. Selain itu, pendidik dapat pula memberikan tugas yang berisi suatu persoalan atau kejadian yang memberikan kesempatan kepada anak didik diminta untuk menunjukkan nilai yang dimilikinya. Sebagai contoh, anak didik diminta menyatakan sikapnya terhadap upaya menolong pemalas, memberikan bantuan terhadap orang kikir, atau hal-hal yang yang bersifat biasa sampai kepada hal yang menimbulkan konflik pada dirinya.

Dari hasil pengamatan, catatan anekdotal, tugas, laporan, dan sebagainya, pendidik memberikan kesimpulan atau pertimbangan tentang pencapaian suatu indikator atau bahkan suatu nilai. Kesimpulan atau pertimbangan itu dapat dinyatakan dalam pernyataan kualitatif sebagai berikut: BT (Belum Terlihat), apabila anak didik belum memperlihatkan tanda-tanda awal perilaku yang dinyatakan dalam indikator. MT (Mulai Terlihat) apabila anak didik sudah mulai memperlihatkan tanda-tanda awal perilaku yang dinyatakan dalam indikator tetapi belum konsisten. MB (Mulai Berkembang), apabila anak didik sudah memperlihatkan berbagai perilaku yang dinyatakan dalam indikator dan mulai konsisten). MK (Memiliki Karakter/Membudaya), apabila anak, didik terus-menerus memperlihatkan perilaku yang dinyatakan dalam indikator secara kotisisten.

\section{Desain Kurikulum Pendidikan Karakter Taman Kanak- Kanak}

Kurikulum pendidikan karakter di TK Negeri Pembina Semarang meliputi: pengembangan kurikulum pendidikan karakter, pembelajaran pendidikan karakter, serta penilaian pendidikan karakter.

1. Pengembangan Kurikulum Pendidikan Karakter

Pengembangan kurikulum pendidikan karakter di TK Negeri Pembina Semarang dirintis sejak tahun 2010, berupa sosialisasi gagasan dan pemantauan pendididikan karakter dari Kementerian Pendidikan Nasional, kemudian diterbitkan SK penunjukan TK Negeri Pembina Semarang sebagai pilot 
proyek pendidikan Karakter. ${ }^{35}$ Selanjutnya tiga pendidik TK Negeri Pembina Semarang dikirim ke TK Budi Mulia 2 Yogyakarta ${ }^{36}$ untuk melakukan kegiatan studi banding dan magang. Hasil studi banding dan magang dari TK Budi Mulia 2 tersebut dijadikan bahan pijakan untuk penyusunan kurikulum pendidikan karakter.

Langkah-langkah pengembangan kurikulum pendidikan karakter di TK Negeri Pembina Semarang adalah: pemetaan nilai-nilai karakter, penyelarasan visi, misi, dan tujuan sesui dengan pendidikan karakter, penyusunan draf kurikulum pendidikan karakter, sosialiasasi internal maupun eksternal, serta melakukan uji coba pendidikan karakter pada tahun pelajaran 2010/2011. Hasil uji coba tersebut selanjunya digunakan sebagai bahan untuk merevisi kurikulum pendididikan karakter yang diimplementasikan pada tahun pelajaran 2011/2012. Sedangkan evaluasi kurikulum pendidikan karakter secara resmi dan menyeluruh akan dilakuan pada tahun 2015, sesuai rencana induk pendidikan karakter yang ditetapkan oleh Kemendiknas. ${ }^{37}$

Pengembangan kurikulum pendidikan karakter melibatkan para pendidik, pegawai administrasi, komite TK (perwakilan orang tua wali), di bawah arahan pengawas pendidikan Kecamatan Gajahmungkur sebagai perwakilan dari unsur Dinas Pendidikan Kota Semarang.

Hasil pemetaan nilai-nilai karakter yang dituangkan dalam kurikulum tersebut kemudian disusun dalam bentuk rencana aksi yang dituangkan dalam program tahunan,

${ }^{35}$ Penunjukan TK Negeri Pembina Semarang sebagai proyek percontohan pendidikan karakter di Jawa Tengah dituangkan dalam SK. Kepala Dinas Pendidikan Kota Semarang nomor: 420/146.A tertanggal 10 Mei 2010, oleh Drs. Akhmad Zaenuri, M.M.

${ }^{36}$ TK Budi Mulia Dua Pandeansari 23, didirikan oleh Kusnasriyati Amin Rais, tanggal 2 Maret 1987, merupakan pionir pendidikan karakter di Indonesia yang meletakkan pendidikan akhlak atau budi pekerti menjadi prioritas utama, di samping materi pendidikan lainnya. Penjelasan tentang akhlak lebih lanjut dapat dirujuk antara lain: Ghazali, M.H.A. al., Ihyâ ' 'Ulûmuddîn, t.t., III, (Bairut: Darul Fikr); Amin, A., Kitâb al-Akhlâq, (Kairo: an-Nahdlah al-Misriyah, 1967); Nata, A., Akhlak Tasawuf, (Jakarta: Raja Grafindo Persada, 2009).

37 Pedoman pelaksanaan pendidikan karakter di Indonesia dimuat dalam: Desain Induk Pendidikan Karakter, Kementerian Pendidikan Nasional Tahun 2010. 
rencana kegiatan mingguan, dan rencana kegiatan harian. Selanjutnya diadakan penyempurnaan bidang metode pembelajaran, media pembelajaran, serta sarana dan prasarana pendidikan.

Pendidikan karakter di TK Negeri Pembina Semarang tidak diajarkan secara mandiri, tetapi diintegrasikan ke dalam kegiatan pembelajaran pada aspek pembiasaan, meliputi: nilai-nilai agama dan moral, serta aspek kemampuan dasar meliputi: fisik-motorik, kognitif, bahasa, sosial emosional, dalam kurikulum pokok, kurikulum muatan lokal, kurikulum kewirausahaan, pendidikan pengembangan diri, kecakapan hidup, serta dalam budaya satuan pendidikan. Pendidik dalam satuan pendidikan berusaha mengintegrasikan nilai-nilai yang dikembangkan dalam pendidikan karakter ke dalam kurikulum, yang dijabarkan dalam rencana kegiatan mingguan (RKM), dan rencana kegiatan harian (RKH). ${ }^{38}$

Sedangkan nilai-nilai pendidikan karakter yang dikembangkan meliputi: religius, jujur, toleransi, disiplin, kerja keras, kreatif, mandiri, demokratis, rasa ingin tahu, semangat kebangsaan, cinta tanah air, menghargai prestasi, bersahabat, cinta damai, gemar membaca, peduli lingkungan, peduli sosial, serta tanggung jawab. ${ }^{39}$

Formulasi pengembangan kurikulum pendidikan karakter di TK NPS dibangun atas prinsip-prinsip yang tertuang dalam desain induk pendidikan karakter, rencana aksi nasional pendidikan karakter, $^{40}$ kurikulum pendidikan karaker terintegrasi dengan semua aspek perkembangan anak di TK, kemudian dikembangkan dalam program tahunan, rencana kegiatan mingguan dan rencana kegiatan harian, penilaian, dan tindak lanjut.

Bentuk kurikulum pendidikan karakter yang dikembangkan di TK Negeri Pembina Semarang lebih dekat dengan

${ }^{38}$ Rencana kegiatan mingguan (RKM), maupun rencana kegiatan harian $(\mathrm{RKH})$, telah memuat rencana pencapaian nilai-nilai karakter yang ditetapkan.

${ }^{39}$ Kurikulum Pendidikan Karakter TK Negeri Pembina Semarang memuat 18 nilai karakter yang dikembangkan serta dijabarkan dalam indikator kegiatan.

${ }^{40}$ Rencana aksi nasional pendidikan karakter merupakan penjabaran dari desain induk pendidikan karakter yang diterbitkan oleh kementerian pendidikan nasional tahun 2010 . 
model curriculum policy-making, ${ }^{41}$ yakni pengembangan kurikulum yang didasarkan pada kebijakan pemerintah untuk melaksanakan program tertentu yang segala aturannya ditetapkan oleh pemerintah secara khusus, meskipun demikian kebijakan yang diberikan oleh pemerintah masih bersifat umum dan belum operasional.

Pengembangan kurikulum pendidikan karakter di TK Negeri Pembina Semarang secara umum telah memenuhi unsur-unsur yang dikemukakan oleh Tyler yakni: menentukan tujuan $^{42}$, menentukan pengalaman belajar, ${ }^{43}$ mengorganisasikan pengalaman belajar, ${ }^{44}$ dan melakukan penilaian. ${ }^{45}$

Pendidikan karakter di TK Negeri Pembina Semarang tidak berdiri sendiri, tetapi diintegrasikan dengan seluruh standar perkembangan anak didik, baik dalam kurikulum pokok, pendidikan kewirausahaan, muatan lokal, pendidik pengembangan diri, serta kurikulum kecakapan hidup.

2. Implementasi Kurikulum Pendidikan Karakter

Penerapan kurikulum pendidikan karakter di TK Negeri Pembina Semarang untuk tahap pertama diprioritaskan pada empat nilai karakter: religius, disiplin, mandiri, serta semangat kebangsaan, sesuai tingkat perkembangan anak TK, kemudian pada tahap kedua dikembangkan pembelajaran karakter secara utuh dengan pijakan delapan belas nilai karakter.

Tujuan pembelajaran di TK Negeri Pembina Semarang adalah upaya pencapaian standar perkembangan anak didik yang berkarakter, dengan cara menciptakan situasi dan kondisi yang kondusif dan edukatif untuk membimbing pertumbuhan dan perkembangan anak didik ke arah yang lebih baik, bukan hanya pada peningkatan prestasi akademis dan pengembangan ilmu pengetahuan semata.

Pendekatan pendidikan karakter meliputi: pembiasaan, keteladanan, pemberdayaan dan pembudayaan, penciptaan

${ }^{41}$ Wiles, J., \& Bondi, J., Curriculum Development a Guide to Practice, Third Edition, (New York: Macmillan Publishing Company, 1989), hlm. 13.

${ }^{42}$ Tyler, Ralp. W., Basic Principles of Curriculum and Instruction, (Chicago: The University of Chicago Press, 1949), hlm. 1-43.

${ }^{43}$ Tyler, Basic Principles ..., hlm. 63-68.

${ }^{44}$ Tyler, Basic Principles ..., hlm. 83-100.

45 Tyler, Basic Principles ..., hlm. 104-123. 
budaya satuan pendidikan, serta pemberian penguatan, baik di dalam ruang kelas, maupun pembelajaran di luar kelas. Pembelajaran pendidikan karakter di samping diintegrasikan dengan kegiatan pembelajaran dalam kurikulum pokok, juga diintegrasikan dengan kurikulum pendidikan kewirausahaan, kurikulum pendidikan muatan lokal, serta kurikulum pendidikan kecakapan hidup, secara integratif dan holistik, sehingga dapat mempermudah pembentukan karakter anak didik sesuai dengan tujuan kegiatan yang ditetapkan. ${ }^{46}$

Adapun media pembelajaran yang diguanakan meliputi: media pembelajaran di luar kelas, dan media pembelajaran di dalam kelas. Media pembelajaran di luar kelas terdiri atas alam sekitar, dan sosial. Sedangkan media pembelajaran di dalam kelas difokuskan pada beberapa area, yakni: area agama dan ketuhanan, area bahasa, area balok, area air dan pasir, area musik, area IPA, area drama, area matematika, area seni, dan area masak, serta alat-alat bermain.

3. Penilaian Pendidikan Karakter

Pelaksanaan penilaian pendidikan karakter di TK Negeri Pembina Semarang didasarkan pada pemahaman terhadap prinsip tumbuh kembang dan belajar anak usia dini, dan diutamakan pelaksanaannya melalui pengamatan secara langsung. Oleh karena itu, kemampuan melakukan pengamatan yang benar bagi pendidik anak usia dini merupakan suatu kompetensi sangat penting.

Setiap pengamatan direkam dalam kegiatan pencatatan. Pendidik sebagai pengamat bukan hanya sekedar mengamati anak-anak untuk mengetahui kegiatan apa saja yang dilakukan anak, tetapi pengamat juga mencatat apa yang diamati sehingga dapat dijadikan sebagai dasar untuk penilaian perkembangan anak. Penilaian dilakukan setiap hari dan berkesinambungan melaui: pengamatan, unjuk kerja, percakapan, dan kumpulan hasil kerja. ${ }^{47}$

${ }^{46}$ Pendidikan karakter secara holistik dalam Islam dapat dirujuk: Sijn, M., 1977, al-Tarbiyah al-Akhlâqiyyah al-Islâmiyyah, (Mesir: Maktabah alKanjiy).

${ }^{47}$ Sesuai pandangan: Seefeldt, C., \& Wasik, B.A., Pendidikan Anak Usia Dini: Menyiapkan Anak Usia Tiga, Empat, dan Lima Tahun Masuk Sekolah, terj. Pius Nasar, (Jakarta: PT Indeks, 2008), hlm. 233-246. 
Penilaian pendidikan karakter dilakukan secara terintegrasi dengan penilain seluruh aspek perkembangan anak didik dalam kurikulum pokok, kurikulum kewirausahaan, kurikulum muatan lokal, serta kurikulum kecakapan hidup secara keseluruhan dan terintegrasi melalui: pengamatan, unjuk kerja, percakapan, dan kumpulan hasil kerja. Hasil penilaian tersebut digunakan oleh pendidik untuk memberikan kesimpulan tentang pencapaian indikator nilainilai karakter.

Hasil penilaian pendidikan karakter dinyatakan dalam pernyataan kualitatif sebagai berikut: BT (Belum Terlihat), apabila anak didik belum memperlihatkan tanda-tanda awal perilaku yang dinyatakan dalam indikator. MT (Mulai Terlihat), apabila anak didik sudah mulai memperlihatkan tanda-tanda awal perilaku yang dinyatakan dalam indikator tetapi belum konsisten. MB (Mulai Berkembang), apabila anak didik sudah memperlihatkan berbagai perilaku yang dinyatakan dalam indikator dan mulai konsisten). MK (Memiliki Karakter/Membudaya), apabila anak didik terusmenerus memperlihatkan perilaku yang dinyatakan dalam indikator secara konsisten.

Evaluasi kurikulum pendidikan karakter yang dilakukan di TK Negeri Pembina Semarang dapat diperoleh simpulan bahwa secara umum capaian nilai-nilai karakter anak didik masuk dalam kategori mulai berkembang (MB), bahkan sebagian besar telah memiliki karakter (MK). Para pendidik dan pegawai lainnya pada umumnya telah memiliki nilai-nilai karakter yang diharapkan (MK). Dilihat dari aspek efektivitas penyelenggaraan pendidikan karakter termasuk dalam kategori cukup efektif (CE). Adapun dari aspek ketercapaian indikator nilai-nilai karakter sebagaimana dalam monitoring dan evaluasi memperoleh nilai capaian: sudah mulai berkembang $(\mathrm{MB})$, bahkan sebagian besar telah memiliki karakter (MK).

\section{Penutup}

Ruang lingkup kurikulum TK Negeri Pembina Semarang didasarkan kepada Peraturan Menteri Pendidikan Nasional Nomor 58 Tahun 2009 tentang standar nasional pendidikan anak usia dini meliputi: aspek pengembangan pembiasaan dan aspek perkem- 
bangan kemampuan dasar. Kurikulum tersebut kemudian dikembangkan sesuai dengan kebutuhan nyata TK Negeri Pembina Semarang dengan memasukkan mulok, dan pengembangan diri, di samping itu juga diintegrasikan dengan pendidikan karakter dan kewirausahaan.

Pembelajaran pendidikan karakter yang dilakukan di TK Negeri Pembina Semarang melalui: (1) Keteladanan dan Pembiasaan, (2) Terintegrasi dengan Pembelajaran, (3) Pendidikan karakter di luar satuan pendidikan, (4) Pengembangan Budaya Satuan Pendidikan, (5) Pengintegrasian Pendidikan Karakter dalam Semua Aspek Pengembangan, (6) Integrasi Pendidikan Karakter dalam Kegiatan Rutin, (7) Pemberdayaan dan Pembudayaan Pendidikan Karakter, (8) Penguatan Pendidikan Karakter.

Penilaian yang dilakukan di TK Negeri Pembina Semarang dilakukan secara terintegrasi dengan penilaian keseluruhan pada aspek pembiasaan dan kemampuan dasar secara umum dalam kurikulum. Pendidikan karakter di TK Negeri Pembina Semarang tidak diajarkan secara mandiri meliputi: nilai-nilai agama dan moral, serta aspek kemampuan dasar meliputi: fisik-motorik, kognitif, bahasa, sosial emosional, dalam kurikulum pokok, kurikulum muatan lokal, kurikulum kewirausahaan, pendidikan pengembangan diri, kecakapan hidup, serta dalam budaya satuan pendidikan. Evaluasi kurikulum pendidikan karakter yang dilakukan di TK Negeri Pembina Semarang dapat diperoleh simpulan bahwa secara umum capaian nilai-nilai karakter anak didik masuk dalam kategori mulai berkembang (MB). Adapun dari aspek ketercapaian indikator nilai-nilai karakter sebagaimana dalam monitoring dan evaluasi memperoleh nilai capaian: sudah mulai berkembang (MB), bahkan sebagian besar telah memiliki karakter (MK).

\section{Kepustakaan}

Amin, A. 1967. Kitab al-Akhlāq. Kairo: an-Nahdlah al-Misriyah. Al-Ghazali. Ihyā Ulümuddn. Jilid III. Bairut: Darul Fikr.

Kementerian Pendidikan Nasional. 2010. Desain Induk Pendidikan Karakter, Jakarta: Depdiknas.

----. 2010. Rencana Aksi Nasional Pendidikan Karakter, Jakarta: Depdiknas 
----. Peraturan Menteri Pendidikan Nasional, Nomor 58 Tahun 2009, tentang Standar Pendidikan Anak Usia Dini, Jakarta: Depdiknas.

----. Kemendiknas. 2010. Pengembangan Pendidikan Budaya dan Karakter Bangsa: Pedoman Sekolah, Jakarta: Balitbang Pusat Kurikulum.

----.2011. Pedoman Pelaksanaan Pendidikan Karakter Berdasarkan Pengalaman di Satuan Pendidikan Rintisan. Jakarta: Balitbang Pusat Kurikulum dan Perbukuan.

Lickona, T. 1992. Educating for Character, How Our Schools Can Teach Respect and Responsibility, New York: Bantam Books.

----. 2004. Character Matter: How to Help Our Children Develop Good Judgment, Integrity, and Other Essential Virtues. New York: Simon \& Schuster.

Majid, A. \& Andayani D. 2011. Pendidikan Karakter Perspektif Islam. Bandung: Remaja Rosdakarya.

Miskawaiyh, I.M.A. 1934. Tahżib al-Akhlāq wa Tathïr al-Araq. Mesir: al-Mathba' ah al-Misriyah.

----.1968. The Refinement of Character, terj. Constantine K. Zuraiyk. Bairut: American University of Beirut.

----1994. Мепијu Kesempurnaan Akhlak, terj. Helmi Hidayat. Bandung: Mizan.

Nata, A. 2009. Akhlak Tasawuf. Jakarta: Raja Grafindo Persada.

Oliva. 1982. Developing the Curriculum. Boston Toronto: Little, Brown and Company.

Seefeldt, C., \& Wasik, B.A. 2008. Pendidikan Anak Usia Dini: Menyiapkan Anak Usia Tiga, Empat, dan Lima Tahun Masuk Sekolah. terj. Pius Nasar, Jakarta: PT Indeks.

Sijn, M. 1977. at-Tarbiyah al-Akhlāqiyyah al-Islāmiyyah. Mesir: Maktabah al-Kanjiy.

Taba, H. 1962. Curriculum Development, Theory and Practice, New York: Harcourt, Brace \& World, Inc.

Trianto. 2011. Desain Pengembangan Pembelajaran Tematik bagi Anak Usia Dini TK/RA \&Anak Kelas SD/MI Awal, Jakarta: Prenada Media Group.

Tyler. 1949.. Basic Principles of Curriculum and Instruction, Chicago: The University of Chicago Press. 
70 | Darmu'in

Wiles, J., \& Bondi. 1989. Curriculum Development a Guide to Practice. Third Edition New York: Macmillan Publishing Company.

Yuliani, N.S. 2009. Konsep Dasar Pendidikan Anak Usia Dini, Jakarta: PT. Indeks.

Zuchdi. 2010. Pendidikan Karakter dengan Pendekatan Komprehensif Terintegrasi dalam Perkuliahan dan Pengembangan Kultur Universitas, Cetakan ke-1. Yogyakarta: UNY Press. 
